\title{
7. AZ ISKOLA KÜLSŐ MEGÍTÉLÉSE
}

\author{
KOCSIS RITA - SUBRT PÉTER
}

\section{Bevezetés}

Az iskolaválasztással kapcsolatos vizsgálatok azt jelzik, hogy egy család életciklusában az első gyermek iskolába kerülése jelentős változásokat hozó esemény (Solymosi, 2013). A kutatások szerint (Berényi, Berkovits és Erőss, 2005, Solymosi, 2013) napjainkban Magyarországon az iskolaválasztás a szülők részéről az első fontos döntés gyermekük életútjával kapcsolatban. Megfigyelhető az egyre nagyobb tudatosság a szülők iskolaválasztásában. A szülők végzettsége meghatározó az iskolaválasztásnál, elsősorban a magasabb iskolai végzettségü szülők tájékozódnak körültekintőbben. Választásukat befolyásolja, hogy hasonló végzettségü szülők gyerekeivel akarják együtt járatni a saját gyerekeiket, mert úgy vélik, hogy ilyen közegben a gyermek megkaphatja a neveléséhez és oktatásához szükséges leghatékonyabb segítséget, valamint a szülő itt biztonságban tudhatja gyermekét. (Berényi, Berkovits és Eröss, 2005, Solymosi, 2013)

Az iskolaválasztás nem tekinthető véletlenszerü folyamatnak. Az óvoda ebben kettős szerepet tölt be. Az óvodáskorú gyermekek szüleinek nagy többsége nem tartja fontosnak, hogy az óvónők általános iskolát ajánljanak nekik, számukra az óvoda legfontosabb funkciója a nevelés, gyermekük szocializációja. Az iskolaválasztásnál azonban szakértőként tekintenek az óvónőre. Az óvónőkben kialakul egy elképzelés arról, hogy a gyermeknek melyik intézmény melyik tagozat való, és erről tájékoztatják is a szülőket. A szülők az óvónő szakmai javaslatai alapján döntenek a gyermek iskolaérettségéről, a számára megfelelő osztály, tagozat és intézmény megválasztásáról. Véleményük több dimenzió mentén alakul, meghatározza azt a többi intézményhez, például társintézményekhez, iskolákhoz, nevelési tanácsadóhoz füződő viszony, az óvoda elhelyezkedése, az intézmény eszmeisége (Berényi, Berkovits és Eröss, 2005).

Az iskolaválasztásnak vannak kézenfekvő indokai: befolyásolja azt a családi kapcsolatrendszer, a szülők életről, boldogulásról vallott nézetei, a gyermek esetleges iskolai kudarcaitól való félelem (Pusztai, 2009, Solymosi, 2013, Tóth, 2015). Az iskolaválasztást meghatározza az iskola közelsége, a tanító személyisége, a gyermek számára biztonságosnak vélt közeg (Solymosi, 2013), a családi hagyományok (Pusztai, 2009), befolyásolja, hogy az idősebb testvért a szülők melyik iskolába íratták be. Léteznek magasabb rendű szülői elvárások is: 
a szülők értékrendje, normái által meghatározott életstratégiák, adaptív vagy maladaptív családi stratégiák, illetve a család pszichológiai jólléte (Solymosi, 2013).

Az általános iskola választásánál a szülők általában figyelembe veszik a korábban szerzett jó tapasztalatokat, a nyolcadik osztályosok szülei föleg a szaktárgyi és a továbbtanulási lehetőségeket mérlegelik. A beiskolázás sikeressége meghatározza az iskolák költségvetési támogatását (Tóth, 2015), az intézmények pedig a felvételi esélyek növelésével jutalmazzák az iskolához „hüséges” családokat (Solymosi, 2013).

Az iskola megítélése befolyásolja a szülőket az iskolaválasztásban (Tóth, 2015). A kérdés az, hogy mennyiben azonos vagy különböző a szülők, illetve a pedagógusok iskoláról alkotott képe (Solymosi, 2013).

\section{A kutatás}

Annak az átfogó kutatásnak a keretében, amely igyekszik kimutatni, hogy egy szakmai fejlesztő iskola milyen szempontokból és milyen mértékben felel meg a közeli jövőben vele támasztandó követelményeknek, indokoltnak gondoltuk egy tipikus gyakorlóiskola jelenlegi megítélésének a vizsgálatát. Az iskola ismertségének, megítélésének egyik mutatójaként az iskolaválasztás előtt álló szülők véleményét szándékoztunk megismerni. Ennek érdekében a gyakorlóiskola vonzáskörzetébe tartozó óvodákba és iskolába juttattunk el egy négy kérdésből álló, az iskolaválasztás szempontjait tartalmazó kérdőívet. A kérdőíveket a szülők önkéntesen, szülői értekezleten töltötték ki.

\section{Kutatásunk céljai a következőek:}

1. Fontosnak gondoljuk, hogy egy regionális központ szerepét betöltő szakmai fejlesztő iskola a vonzáskörzetében ismert és elismert intézmény legyen. A jelenlegi helyzet feltárása egyfelől választ ad arra a kérdésre, hogy a gyakorlóiskola jelenleg mennyiben felel meg ennek az elvárásnak, azaz mennyire ismert vonzáskörzetében, és mennyire tartják jó iskolának.

2. Az adatok további elemzéséből kideríthetjük, hogy a szülők által vélt hiányosságok mennyiben tükrözik az iskola valós helyzetét, illetve milyen eltérés mutatkozik a valós helyzet és a szülők által feltételezett kép között.

Kutatási céljaink jelentőségét az adja, hogy az első esetben egy tipikus gyakorlóiskola valós oktató-nevelő munkájára vonatkozóan, míg a másodikban egy jövendő szakmai fejlesztő iskola marketing-, tájékoztató tevékenységére vonatkozóan fogalmazhatunk meg következtetéseket és javaslatokat. 


\section{Kutatásunk hipotézisei a következők voltak:}

H1. A gyakorlóiskola az egyetemmel évtizedek óta fennálló szoros együttműködése, nagy szakmai múltja és központi elhelyezkedése miatt a szülők által elismert intézmény.

H2. A gyermeküknek tudatosan iskolát választó szülők fontosnak tartják és választásukkal elismerik a gyakorlóiskola képzési kínálatát, oktató-nevelő munkáját. A gyakorlóiskola képzési profilja és a szülők elvárásai összhangban vannak, ezt a szülők az iskolaválasztásnál figyelembe veszik.

H3. A megkérdezett szülők számára rendkívül fontos a családtagok, ismerősök véleménye az iskolaválasztás előtt.

H4. Az óvónők vagy a tanuló általános iskolai tanárai mint a gyermeket jól ismerő szakemberek véleménye szintén meghatározza a megkérdezett szülők iskolaválasztását.

\subsection{A kutatás módszertani jellemzői}

\subsubsection{A kutatás során alkalmazott mérőeszközök}

A kérdőív három iskolaválasztásra vonatkozó kérdésből, illetve a háttérváltozókkal kapcsolatos kérdésekből állt. Az első és a második kérdés az óvodások szüleinek készült kérdőívben 21 itemből, a nyolcadik osztályosok szüleinek készült kérdőívben 22 itemből állt, és az iskolaválasztásnál fontosnak tartott szempontokra kérdezett rá. A második kérdésnél arra kértük a szülőket, hogy válasszanak ki a megadott listából két általános iskolát, illetve két gimnáziumot, ahová szívesen beíratnák gyermeküket. Harmadik iskolaként a gyakorlóiskolát adtuk meg. Arra kértük a szülőket, hogy egy háromfokú skálán értékeljék ezt a három iskolát a megadott szempontok alapján. A harmadik kérdés tíz itemből állt. Arra kérdeztünk rá, hogy a megadott állítások közül melyik az a maximum három tényező, amely leginkább befolyásolja az iskolaválasztásukat. Mindhárom feladatnál utolsó itemként nyílt végü kérdést adtunk meg, mely egyéb szempontok megadását tette lehetővé a válaszadók számára. A nyílt végű kérdésre adott válaszok elemzését induktív tartalomelemzéssel két kódoló végezte, a személyi triangulációval biztosítottuk a kvalitatív tartalomelemzés érvényességét és megbízhatóságát (Sántha, 2015). Az elemzés eredményeit mindkét kérdőív esetében a leíró statisztikai elemzések után közöljük.

\subsubsection{A kutatásban részt vevők jellemzői}

A kérdőíveket a nagycsoportos óvodások, illetve a nyolcadik osztályos tanulók szüleinél vettük fel. Rákérdeztünk a válaszadó nemére, életkorára, lakóhelyére és legmagasabb iskolai végzettségére. A minta elemszáma az óvodások szüleinél 102 fó, a nyolcadik osztályosok szüleinél 293. Feltűnő, hogy sok, érdemi választ nem tartalmazó kérdőív érkezett vissza. $\mathrm{Az}$ 5. és 6. táblázatban feltüntettük az érdemi válaszok hiányának a számát az óvodások, illetve a nyolcadik osztályosok szüleinél. 
A válaszadók többsége mindkét részminta esetén nő (1. táblázat). Az óvodások szüleinek majdnem fele 36 és 40 év közötti, a nyolcadik osztályosok szüleinek több mint 40 százaléka 41 és 45 év közötti (2. táblázat). Az óvodások szüleinek több mint fele a belváros közelében, illetve a belvárosban lakik, csupán 16,5 százaléka él vidéken. A nyolcadik osztályosok szüleinek majdnem fele vidéki (3. táblázat). Ennek az az oka, hogy a kérdőíveket a városi óvodákban töltették ki, amíg a kérdőívet visszaküldő általános iskolák majdnem fele vidéken található. A válaszadók legmagasabb iskolai végzettsége a két részminta esetén eltérő összetételü. Az óvodások szüleinek több mint fele föiskolát, egyetemet végzett. Közöttük kevesebb a középfokú végzettséggel rendelkezők aránya. A nyolcadik osztályosok szüleinek csupán egyharmada diplomás, közel 50 százalékuk középfokú végzettséggel rendelkezik (4. táblázat).

\begin{tabular}{|c|c|c|c|c|}
\hline $\begin{array}{c}\text { a válaszadó } \\
\text { neme }\end{array}$ & $\begin{array}{c}\text { óvodások } \\
\text { szüleinek } \\
\text { száma }\end{array}$ & $\begin{array}{c}\text { óvodások } \\
\text { szüleinek } \\
\text { százalékos } \\
\text { aránya }\end{array}$ & $\begin{array}{c}\text { 8. osztályos } \\
\text { diákok } \\
\text { szüleinek } \\
\text { száma }\end{array}$ & $\begin{array}{c}\text { 8. osztályos } \\
\text { diákok } \\
\text { szüleinek } \\
\text { százalékos } \\
\text { aránya }\end{array}$ \\
\hline férfi & 12 & 11,7 & 40 & 13,6 \\
\hline nő & 90 & 88,3 & 253 & 86,4 \\
\hline
\end{tabular}

7.1. táblázat: A válaszadók nemek szerinti megoszlása $(\mathrm{N}=395)$

\begin{tabular}{|l|c|c|}
\hline a válaszadó életkora & óvodások szülei & 8. osztályosok szülei \\
\hline 25 év alatt & $1 \%$ & $1 \%$ \\
\hline $\mathbf{2 6 - 3 0}$ év & $6,2 \%$ & $0,5 \%$ \\
\hline $\mathbf{3 1 - 3 5}$ év & $26,8 \%$ & $5,6 \%$ \\
\hline $\mathbf{3 6 - 4 0}$ év & $45,4 \%$ & $28,1 \%$ \\
\hline $\mathbf{4 1 - 4 5}$ év & $16,5 \%$ & $42,7 \%$ \\
\hline 45 év fölött & $4,1 \%$ & $22,1 \%$ \\
\hline
\end{tabular}

7.2. táblázat: A válaszadók életkor szerinti megoszlása $(\mathrm{N}=395)$ 


\begin{tabular}{|l|c|c|}
\hline a válaszadó lakóhelye & óvodások szülei & $\mathbf{8 . ~ o s z t a ́ l y o s o k ~ s z u ̈ l e i ~}$ \\
\hline belváros & $22,7 \%$ & $4,9 \%$ \\
\hline belváros közeli & $34,0 \%$ & $14,2 \%$ \\
\hline lakótelep & $10,3 \%$ & $19,0 \%$ \\
\hline kertváros & $16,5 \%$ & $17,5 \%$ \\
\hline vidék & $16,5 \%$ & $44,0 \%$ \\
\hline
\end{tabular}

7.3. táblázat: A válaszadók lakóhely szerinti megoszlása $(\mathrm{N}=395)$

\begin{tabular}{|c|c|c|}
\hline $\begin{array}{l}\text { a válaszadó legmagasabb } \\
\text { iskolai végzettsége }\end{array}$ & óvodások szülei & 8. osztályosok szülei \\
\hline kevesebb mint 8 osztály & $0 \%$ & $1,1 \%$ \\
\hline befejezett általános iskola & $0 \%$ & $2,6 \%$ \\
\hline $\begin{array}{l}\text { befejezett szakmunkás- } \\
\text { képző, szakiskola }\end{array}$ & $6,2 \%$ & $19,4 \%$ \\
\hline $\begin{array}{l}\text { befejezett szakközépis- } \\
\text { kola, technikum }\end{array}$ & $10,3 \%$ & $15,7 \%$ \\
\hline befejezett gimnázium & $3,1 \%$ & $11,6 \%$ \\
\hline $\begin{array}{l}\text { A válaszadók legmaga- } \\
\text { sabb iskolai végzettség } \\
\text { szerinti megoszlása }(\mathrm{N}= \\
395)\end{array}$ & $\begin{array}{l}\text { A válaszadók legmaga- } \\
\text { sabb iskolai végzettség } \\
\text { szerinti megoszlása ( } \mathrm{N}= \\
395)\end{array}$ & $\begin{array}{c}\text { A válaszadók legmaga- } \\
\text { sabb iskolai végzettség } \\
\text { szerinti megoszlása ( } \mathrm{N}= \\
395)\end{array}$ \\
\hline $\begin{array}{l}\text { befejezett felsőfokú } \\
\text { szakképzés }\end{array}$ & $15,5 \%$ & $10,4 \%$ \\
\hline $\begin{array}{l}\text { befejezett föiskola, } \\
\text { egyetem }\end{array}$ & $54,6 \%$ & $32,8 \%$ \\
\hline $\begin{array}{l}\text { megszerzett doktori } \\
\text { fokozat }\end{array}$ & $2,1 \%$ & $1,1 \%$ \\
\hline
\end{tabular}

7.4. táblázat: A válaszadók legmagasabb iskolai végzettség szerinti megoszlása $(\mathrm{N}=395)$ 


\begin{tabular}{|c|c|c|c|c|c|c|}
\hline & \multirow[t]{2}{*}{ 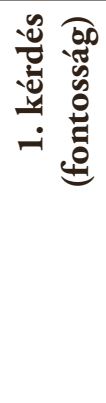 } & \multicolumn{3}{|c|}{ 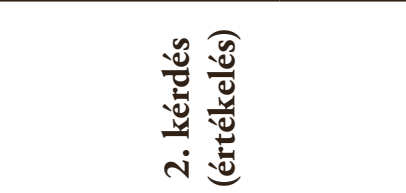 } & \multirow[t]{2}{*}{ 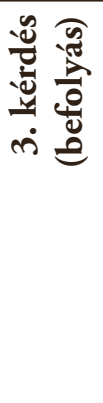 } & \multirow[t]{2}{*}{ 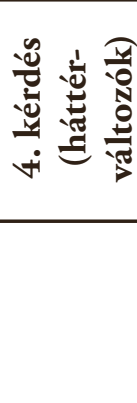 } \\
\hline & & $\begin{array}{l}\frac{\pi}{0} \\
\frac{\pi}{9} \\
\stackrel{0}{-1}\end{array}$ & $\begin{array}{l}\frac{\pi}{0} \\
\frac{y}{9} \\
\dot{0}\end{array}$ & 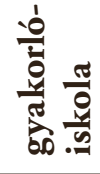 & & \\
\hline Nem töltötte ki. & - & 27 & 43 & 42 & 6 & 5 \\
\hline $\begin{array}{l}\text { 10-nél kevesebb } \\
\text { érdemi választ adott. }\end{array}$ & \multirow[t]{3}{*}{-} & 19 & 22 & 20 & \multirow[t]{3}{*}{ - } & \multirow[t]{3}{*}{ - } \\
\hline $\begin{array}{l}\text { Nem adott érdemi } \\
\text { választ. (minden } \\
\text { válasz "nem tudom") }\end{array}$ & & 2 & 7 & 13 & & \\
\hline Összesen & & 48 & 72 & 75 & & \\
\hline
\end{tabular}

7.5. táblázat: Az érdemi válaszok hiányának száma az óvodások szüleinek kérdőíveiben $(\mathrm{N}=102)$

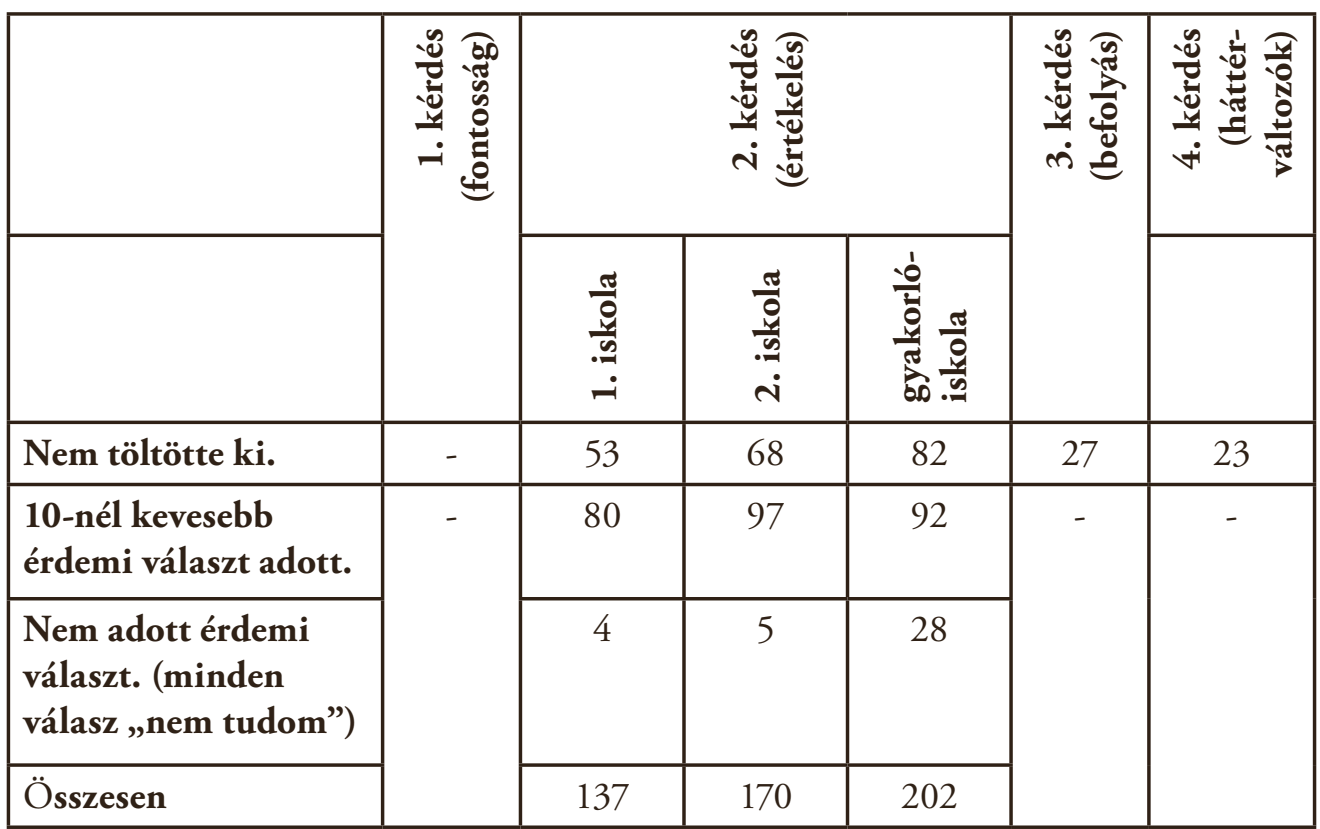

7.6. táblázat: Az érdemi válaszok hiányának száma a nyolcadik osztályosok szüleinek kérdőíveiben $(\mathrm{N}=293)$ 
Az eredmények alapján úgy tünik, hogy viszonylag sok volt a bizonytalan, tájékozatlan szülő (5. és 6. táblázat). Ez arra hívja fel a figyelmet, hogy az iskolák, így a gyakorlóiskola esetében a jelenleginél fontosabb szerepet kaphatna a szülők tájékoztatása.

Általában is segíteni kellene a szülőket azokkal a tényezőkkel kapcsolatban, amelyekre érdemes figyelmet fordítani az iskolaválasztásnál, a gyakorlóiskola pedig vonzerejének növelése érdekében jobban megismertethetné saját tevékenységét a szülőkkel és az iskolaválasztásban fontos szerepet játszó pedagógusokkal is.

\section{Eredmények}

\subsection{Az óvodások szüleinek véleménye}

Az elemzésnél elsőként összehasonlítottuk a szülők által legjobbnak ítélt két iskola átlagát a gyakorlóiskola átlagával (ld. 7. táblázat). A táblázat harmadik oszlopában feltüntettük az átlagok közötti különbségeket, ezzel igazolni kívántuk az iskola elismertségére vonatkozó hipotézisünket. Amennyiben az iskolák pozitív tulajdonságait megjelölő itemek közül a gyakorlóiskola túlnyomó többségben magasabb átlagpontszámot ér el, akkor bebizonyosodik az a hipotézisünk, hogy a gyakorlóiskola elismert intézmény a város általános iskolái között.

\begin{tabular}{|c|c|c|c|c|}
\hline & itemek & $\begin{array}{c}\text { általános } \\
\text { iskolák } \\
\text { átlaga }\end{array}$ & $\begin{array}{c}\text { gyakorló- } \\
\text { iskola } \\
\text { átlaga }\end{array}$ & $\begin{array}{l}\text { az átlagok } \\
\text { különbsége }\end{array}$ \\
\hline 1. & Az iskola könnyen megközelíthető. & 2,73 & 2,48 & $-0,25$ \\
\hline 2. & Megoldott az akadálymentesítés. & 2,24 & 2,58 & $+0,34$ \\
\hline 3. & $\begin{array}{l}\text { Az iskolai légkör elfogadó, } \\
\text { gyermekközpontú. }\end{array}$ & 2,65 & 2,33 & $-0,32$ \\
\hline 4. & A pedagógusok jól tanítanak. & 2,75 & 2,67 & $-0,08$ \\
\hline 5. & $\begin{array}{l}\text { A pedagógusok nyitottak, rugal- } \\
\text { masak, megértőek. }\end{array}$ & 2,72 & 2,54 & $-0,18$ \\
\hline 6. & A pedagógusok kiváló nevelők. & 2,59 & 2,48 & $-0,11$ \\
\hline
\end{tabular}




\begin{tabular}{|c|c|c|c|c|}
\hline \multicolumn{5}{|c|}{$\begin{array}{l}\text { Kérjük, értékelje, hogy mennyire tartja fo } \\
\text { tás szempontjából! Válaszát soronként az } \\
1 \text { = nem fontos } \\
2 \text { = közepesen fontos } \\
3 \text { = nagyon fontos }\end{array}$} \\
\hline 7. & $\begin{array}{l}\text { A pedagógusok igazságosan } \\
\text { értékelnek. }\end{array}$ & 2,60 & 2,56 & $-0,04$ \\
\hline 8. & $\begin{array}{l}\text { Színvonalas az idegen nyelvek } \\
\text { oktatása. }\end{array}$ & 2,46 & 2,72 & $+0,26$ \\
\hline 9. & $\begin{array}{l}\text { Sok szakkör, sportkör indul a tanu- } \\
\text { lói igényeknek megfelelően. }\end{array}$ & 2,51 & 2,67 & $+0,16$ \\
\hline 10. & Színvonalas a tagozatos képzés. & 2,51 & 2,59 & $+0,08$ \\
\hline 11. & Színvonalas a művészeti képzés. & 2,22 & 2,67 & $+0,45$ \\
\hline 12. & $\begin{array}{l}\text { Van lehetőség bontott (kis } \\
\text { létszámú) csoportokban történő } \\
\text { tanulásra. }\end{array}$ & 2,35 & 2,38 & $+0,03$ \\
\hline 13. & $\begin{array}{l}\text { A pedagógusok törekednek a tanu- } \\
\text { lásban lemaradók felzárkóztatására. }\end{array}$ & 2,57 & 2,52 & $-0,05$ \\
\hline 14. & $\begin{array}{l}\text { Van lehetőség versenyeken való } \\
\text { részvételre. }\end{array}$ & 2,64 & 2,74 & $+0,10$ \\
\hline 15. & $\begin{array}{l}\text { Van lehetőség erdei iskolában, } \\
\text { nyári táborokban való részvételre. }\end{array}$ & 2,57 & 2,65 & $+0,08$ \\
\hline 16. & $\begin{array}{l}\text { A gyerekek jól érzik magukat } \\
\text { az osztályközösségben. }\end{array}$ & 2,71 & 2,65 & $-0,06$ \\
\hline 17. & $\begin{array}{l}\text { A pedagógusok partnerként kezelik } \\
\text { a szülőket. }\end{array}$ & 2,69 & 2,70 & $+0,01$ \\
\hline 18. & Kicsi a lemorzsolódás. & 2,52 & 2,57 & $+0,05$ \\
\hline 19. & $\begin{array}{l}\text { Használnak reformpedagógiai } \\
\text { módszereket (például Jenaplan, } \\
\text { Waldorf). }\end{array}$ & 2,17 & 2,11 & $-0,06$ \\
\hline 20. & Elismerten jó iskola. & 2,67 & 2,75 & $+0,08$ \\
\hline
\end{tabular}

\section{7. táblázat: Az általános iskolák és a gyakorlóiskola megítélésének átlagai és azok különbségei az óvodások szüleinek értékelése alapján $(\mathrm{N}=102)$}

A húsz itemből az gyakorlóiskolánál tizenegy item esetében pozitív irányú különbséget találtunk (7. táblázat). A legnagyobb különbség a művészeti képzésnél tapasztalható 
(„Színvonalas a művészeti képzés”; +0,45). A második helyen a „Megoldott az akadálymentesítés” item áll $(+0,34)$. A harmadik helyen a „Színvonalas az idegen nyelvek oktatása” item található $(+0,26)$. Kilenc esetben negatív eltérést tapasztaltunk a gyakorlóiskola szempontjából. A legnagyobb negatív különbséget „Az iskolai légkör elfogadó, gyermekközpontú” itemnél találtuk (-0,32). A második legnagyobb arányú negatív eltérés „Az iskola könnyen megközelítheto”” itemnél található $(-0,25)$. A harmadik helyen „A pedagógusok nyitottak, rugalmasak, megértőek" item szerepel $(-0,18)$.

A kilenc esetből azonban hét esetben nagyon közeli eredményeket találtunk a másik két általános iskola átlagához viszonyítva, ez a tendencia tapasztalható a pozitív irányú eltérések esetében is. Igazolódott számunkra, hogy a gyakorlóiskola a város elismert iskolái közé tartozik, bár a többi iskolához képest jelentős különbség az esetek többségében sem pozitív, sem negatív irányban nem tapasztalható a gyakorlóiskola megítélésében.

A 8. táblázatban összehasonlítottuk az itemek szülők által meghatározott fontossági sorrendjét a gyakorlóiskola értékelésénél kialakult rangsorral. A táblázat harmadik és negyedik oszlopában kiemeltük az itemek rangsorát. Ezzel a vizsgálattal azt a feltételezésünket kívántuk igazolni, hogy a gyakorlóiskola profilja összhangban van a szülők elvárásaival.

Kérjük, értékelje, hogy mennyire tartja fontosnak az alábbi állításokat az iskolaválasztás szempontjából! Válaszát soronként az alábbi számok bekarikázásával jelölheti:

$1=$ nem fontos

2 = közepesen fontos

$3=$ nagyon fontos

\begin{tabular}{|l|l|l|l|l|l|}
\hline & itemek & $\begin{array}{c}\text { fontosság } \\
\text { átlaga }\end{array}$ & $\begin{array}{c}\text { gyakorló- } \\
\text { iskola } \\
\text { átlaga }\end{array}$ & $\begin{array}{c}\text { fontosság } \\
\text { rangsora }\end{array}$ & $\begin{array}{c}\text { gyakorló- } \\
\text { iskola } \\
\text { rangsora }\end{array}$ \\
\hline 1. & $\begin{array}{l}\text { A pedagógusok nyitot- } \\
\text { tak, rugalmasak, } \\
\text { megértóek. }\end{array}$ & 2,99 & 2,54 & $\mathbf{1 .}$ & $\mathbf{1 4 .}$ \\
\hline 2. & $\begin{array}{l}\text { A pedagógusok jól } \\
\text { tanítanak. }\end{array}$ & 2,98 & 2,67 & $\mathbf{2 .}$ & $\mathbf{6 .}$ \\
\hline 3. & $\begin{array}{l}\text { Az iskolai légkör elfo- } \\
\text { gadó, gyermekközpontú. }\end{array}$ & 2,97 & 2,33 & $\mathbf{3 .}$ & $\mathbf{1 9 .}$ \\
\hline 4. & $\begin{array}{l}\text { A gyerekek jól } \\
\text { érzik magukat } \\
\text { az osztályközösségben. }\end{array}$ & 2,95 & 2,64 & $\mathbf{4 .}$ & $\mathbf{9 .}$ \\
\hline 5. & $\begin{array}{l}\text { A pedagógusok igazságo- } \\
\text { san értékelnek. }\end{array}$ & 2,94 & 2,56 & $\mathbf{5 .}$ & $\mathbf{1 3 .}$ \\
\hline
\end{tabular}




\begin{tabular}{|c|c|c|c|c|c|}
\hline \multicolumn{6}{|c|}{$\begin{array}{l}\text { Kérjük, értékelje, hogy mennyire tartja fontosnak az alábbi állításokat az iskolaválasz- } \\
\text { tás szempontjából! Válaszát soronként az alábbi számok bekarikázásával jelölheti: } \\
1 \text { = nem fontos } \\
2 \text { = közepesen fontos } \\
3 \text { = nagyon fontos }\end{array}$} \\
\hline & itemek & $\begin{array}{c}\text { fontosság } \\
\text { átlaga }\end{array}$ & $\begin{array}{l}\text { gyakorló- } \\
\text { iskola } \\
\text { átlaga }\end{array}$ & $\begin{array}{c}\text { fontosság } \\
\text { rangsora }\end{array}$ & $\begin{array}{l}\text { gyakorló- } \\
\text { iskola } \\
\text { rangsora }\end{array}$ \\
\hline 6. & $\begin{array}{l}\text { A pedagógusok partner- } \\
\text { ként kezelik a szülőket. }\end{array}$ & 2,92 & 2,7 & 6. & 4. \\
\hline 7. & $\begin{array}{l}\text { A pedagógusok kiváló } \\
\text { nevelők. }\end{array}$ & 2,88 & 2,48 & 7. & 16,5 \\
\hline 8. & $\begin{array}{l}\text { Színvonalas a tagozatos } \\
\text { képzés. }\end{array}$ & 2,74 & 2,59 & 8. & 10. \\
\hline 9. & $\begin{array}{l}\text { A pedagógusok töreked- } \\
\text { nek a tanulásban lemara- } \\
\text { dók felzárkóztatására. }\end{array}$ & 2,69 & 2,52 & 9. & 15. \\
\hline 10. & $\begin{array}{l}\text { Színvonalas az idegen } \\
\text { nyelvek oktatása. }\end{array}$ & 2,62 & 2,72 & 10. & 3. \\
\hline 11. & $\begin{array}{l}\text { Az iskola könnyen } \\
\text { megközelíthető. }\end{array}$ & 2,51 & 2,48 & 11. & 16,5 \\
\hline 12. & $\begin{array}{l}\text { Van lehetőség bontott } \\
\text { (kis létszámú) csoportok- } \\
\text { ban történő tanulásra. }\end{array}$ & 2,46 & 2,38 & 12. & 18. \\
\hline 13. & Elismerten jó iskola. & 2,35 & 2,75 & 13. & 1. \\
\hline 14. & $\begin{array}{l}\text { Sok szakkör, sportkör } \\
\text { indul a tanulói igények- } \\
\text { nek megfelelően. }\end{array}$ & 2,34 & 2,67 & 14. & 6. \\
\hline 15. & $\begin{array}{l}\text { Van lehetőség versenye- } \\
\text { ken való részvételre. }\end{array}$ & 2,24 & 2,74 & 15. & 2. \\
\hline 16. & $\begin{array}{l}\text { Van lehetőség erdei isko- } \\
\text { lában, nyári táborokban } \\
\text { való részvételre. }\end{array}$ & 2,23 & 2,65 & 16. & 8. \\
\hline 17. & Kicsi a lemorzsolódás. & 2,18 & 2,57 & 17. & 12. \\
\hline 18. & $\begin{array}{l}\text { Színvonalas a müvészeti } \\
\text { képzés. }\end{array}$ & 2,09 & 2,67 & 18. & 6. \\
\hline
\end{tabular}


Kérjük, értékelje, hogy mennyire tartja fontosnak az alábbi állításokat az iskolaválasztás szempontjából! Válaszát soronként az alábbi számok bekarikázásával jelölheti:

$1=$ nem fontos

2 = közepesen fontos

3 = nagyon fontos

\begin{tabular}{|l|l|l|l|l|l|}
\hline itemek & $\begin{array}{c}\text { fontosság } \\
\text { átlaga }\end{array}$ & $\begin{array}{c}\text { gyakorló- } \\
\text { iskola } \\
\text { átlaga }\end{array}$ & $\begin{array}{c}\text { fontosság } \\
\text { rangsora }\end{array}$ & $\begin{array}{c}\text { gyakorló- } \\
\text { iskola } \\
\text { rangsora }\end{array}$ \\
\hline 19. & $\begin{array}{l}\text { Használnak reformpe- } \\
\text { dagógiai módszereket } \\
\text { például Jenaplan, } \\
\text { Waldorf). }\end{array}$ & 1,97 & 2,11 & $\mathbf{1 9 .}$ & $\mathbf{2 0 .}$ \\
\hline 20. & $\begin{array}{l}\text { Megoldott } \\
\text { az akadálymentesítés. }\end{array}$ & 1,72 & 2,58 & $\mathbf{2 0 .}$ & $\mathbf{1 1 .}$ \\
\hline
\end{tabular}

7.8. táblázat: Az egyes szempontok fontosságának megítéléséből és a gyakorlóiskola ugyanezen szempontok szerinti értékeléséből származó átlagok és rangsorhelyek összehasonlítása az óvodások szüleinek értékelése alapján $(\mathrm{N}=102)$

Általában igen nagy eltéréseket találtunk a szülők fontossági sorrendje és a gyakorlóiskoláról kialakult rangsor tekintetében. Egy esetben találtunk megközelítő egyezést a rangsorokban [„,Használnak reformpedagógiai módszereket (például. Jenaplan, Waldorf)” - 19./20. hely). Két esetben kettő rangsorbeli különbséget találtunk (,,Színvonalas a tagozatos képzés” - 8./10. hely; „A pedagógusok partnerként kezelik a szülolket”- 6./4. hely). A legnagyobb eltérést a szülők által felállított fontossági sorrend és az gyakorlóiskolára jellemző rangsor között az alábbi esetekben találtunk:

- „Az iskolai légkör elfogadó, gyermekközpontú.” (3./19. hely)

- „A pedagógusok nyitottak, rugalmasak, megértőek.” (1./14. hely)

- „Van lehetőség versenyeken való részvételre.” (15./2. hely)

- „Elismerten jó iskola.” (13./1. hely)

Érdemes felfigyelni arra, hogy a szülök által a legfontosabbnak tartott öt jellemzö közül négyben a gyakorlóiskola viszonylag gyengén ,teljesit”, míg a gyakorló kimagasló erényeit (elismerten jó iskola, színvonalas az idegen nyelvek oktatása, van lehetőség versenyeken való részvételre, színvonalas a művészeti képzés) kevésbé tartják fontosnak az óvodások szülei.

Az iskolaválasztásnál fontosnak tartott szempontok közül négy esetben javasoltak a szülők a megadottakon kívül fontos szempontokat, amelyek a következőek voltak: a válaszadó 
szülők az iskolaválasztás szempontjából fontosnak tartják az intézmény felszereltségét, a speciális étkeztetés megoldását, a gyermek egyéniségének figyelembevételét. Egy esetben a „,nem zsúfolt” választ kaptuk, amely vélhetően a tanulócsoportok optimális létszámára vonatkozik.

Az átlagok arra utalnak, hogy a gyakorlóiskola a szülői elvárásokhoz közeli eredményeket mutat fel. A szülők gyakorlóiskoláról alkotott képe és a szülői elvárások között azonban jelentős rangsorbeli eltérések vannak. Ez arra utalhat, hogy az iskola erényeivel ugyan tisztában vannak a szülők, de a számukra legfontosabbnak tartott érvek nem hangsúlyosak a gyakorlóiskoláról alkotott megítélésben. A jó hírű, elismert gyakorlóiskola talán nagyobb hangsúlyt fektet arra, hogy a szülők megismerjék példaértékű oktatási profilját, és kevesebb teret kap az intézmény nevelési koncepciójának megismertetése.

Egy iskola légkörére, a pedagógusok nyitottságára, rugalmasságára, igazságosságára utaló tényezöcsoportra érdemes volna nagyobb hangsúlyt forditani.

A huszonegyedik itemnél a nyílt végű kérdésre három válasz érkezett. Az első válasz nem tartalmaz információt a gyakorlóiskolával kapcsolatban, a második válasz jóra értékeli a gyakorlóiskola internetes hozzáférhetőségét, a harmadik válasz kiemeli a túl sok ülés és folyamatos koncentráció problémáját. Ebből a szempontból a válaszadó gyenge minősítést ad a gyakorlóiskolának.

A második kérdéshez hat megjegyzés érkezett. A válaszadók a lap szélére leírták annak okát, hogy miért nem tudják értékelni az iskolákat. Három fö nem ismeri az intézményeket, kettő szülő a nyílt nap után tudna válaszolni, egy válaszadó még nem gondolkodott az iskolaválasztáson. A válaszok általában problémákat fogalmaznak meg. A szülők tájékozatlansága az iskolákkal kapcsolatban általános jelenség. Érdemes jóval nagyobb hangsúlyt fektetni a szülők tájékoztatására, az iskolákban zajló élet bemutatásra.

\subsection{A 8. osztályosok szüleinek véleménye}

Az elemzés további részében a nyolcadik osztályosok szüleinek kérdőíveit dolgoztuk fel. Elsőként összehasonlítottuk a három iskola átlagát a gyakorlóiskola átlagával (9. táblázat). A különbségeket a táblázat utolsó oszlopában tüntettük fel. Ezzel a kérdőívvel a gyakorlóiskola gimnáziumi tagozatának elismertségére vonatkozó hipotézisünket kívántuk igazolni.

\begin{tabular}{|l|l|c|c|c|}
\hline & itemek & $\begin{array}{c}\text { közép- } \\
\text { iskolák } \\
\text { átlaga }\end{array}$ & $\begin{array}{c}\text { gyakorló- } \\
\text { iskola átlaga }\end{array}$ & $\begin{array}{c}\text { az átlagok } \\
\text { különbsége }\end{array}$ \\
\hline 1. & $\begin{array}{l}\text { Az iskola könnyen } \\
\text { megközelíthető. }\end{array}$ & 2,62 & 2,65 & $+\mathbf{0 , 0 3}$ \\
\hline
\end{tabular}




\begin{tabular}{|l|l|c|c|c|}
\hline & itemek & $\begin{array}{c}\text { közép- } \\
\text { iskolák } \\
\text { átlaga }\end{array}$ & $\begin{array}{c}\text { gyakorló- } \\
\text { iskola átlaga }\end{array}$ & $\begin{array}{c}\text { az átlagok } \\
\text { különbsége }\end{array}$ \\
\hline 2. & $\begin{array}{l}\text { Megoldott } \\
\text { az akadálymentesítés. }\end{array}$ & 2,52 & 2,58 & $\mathbf{+ 0 , 0 6}$ \\
\hline 3. & $\begin{array}{l}\text { A pedagógusok szaktárgyi } \\
\text { tudása kiemelkedően jó. }\end{array}$ & 2,85 & 2,74 & $-0,11$ \\
\hline 4. & $\begin{array}{l}\text { A pedagógusok nyitottak, } \\
\text { rugalmasak, megértőek. }\end{array}$ & 2,64 & 2,63 & $-0,01$ \\
\hline 5. & A pedagógusok kiváló nevelök. & 2,63 & 2,54 & $-0,09$ \\
\hline 6. & $\begin{array}{l}\text { A pedagógusok igazságosan } \\
\text { értékelnek. }\end{array}$ & 2,62 & 2,58 & $-0,04$ \\
\hline 7. & $\begin{array}{l}\text { Színvonalas az idegen nyelvek } \\
\text { oktatása. }\end{array}$ & 2,80 & 2,59 & $-0,21$ \\
\hline 8. & $\begin{array}{l}\text { Van lehetőség külföldi cseredi- } \\
\text { ákprogramban való részvételre. }\end{array}$ & 2,54 & 2,37 & $-0,17$ \\
\hline 9. & $\begin{array}{l}\text { Színvonalas az informatikai } \\
\text { képzés. }\end{array}$ & 2,62 & 2,53 & $-0,09$ \\
\hline 10. & $\begin{array}{l}\text { Az iskolából sok gyerek tanul } \\
\text { tovább jó egyetemeken, } \\
\text { föiskolákon. }\end{array}$ & 2,82 & 2,59 & $-0,23$ \\
\hline 11. & $\begin{array}{l}\text { Sok szakkör, sportkör } \\
\text { indul a tanulói igényeknek } \\
\text { megfelelöon. }\end{array}$ & 2,43 & 2,51 & $\mathbf{+ 0 , 0 8}$ \\
\hline 12. & $\begin{array}{l}\text { Színvonalas a müvészeti } \\
\text { képzés. }\end{array}$ & 2,05 & 2,54 & $\mathbf{+ 0 , 4 9}$ \\
\hline 13. & $\begin{array}{l}\text { Van lehetőség bontott (kis } \\
\text { létszámú) csoportokban } \\
\text { történő tanulásra. }\end{array}$ & 2,50 & 2,46 & $-0,04$ \\
\hline 14. & $\begin{array}{l}\text { A pedagógusok törekednek } \\
\text { a tanulásban lemaradók } \\
\text { felzárkóztatására. }\end{array}$ & 2,54 & 2,66 & $\mathbf{+ 0 , 1 2}$ \\
\hline 15. & $\begin{array}{l}\text { Van lehetőség a versenyeken } \\
\text { való részvételre. }\end{array}$ & 2,76 & 2,75 & $-0,01$ \\
\hline 16. & Nagyon színes a diákélet. & 2,62 & 2,60 & $-0,02$ \\
\hline
\end{tabular}




\begin{tabular}{|l|l|c|c|c|}
\hline & itemek & $\begin{array}{c}\text { közép- } \\
\text { iskolák } \\
\text { átlaga }\end{array}$ & $\begin{array}{c}\text { gyakorló- } \\
\text { iskola átlaga }\end{array}$ & $\begin{array}{c}\text { az átlagok } \\
\text { különbsége }\end{array}$ \\
\hline 17. & $\begin{array}{l}\text { A gyerekek jól érzik magukat } \\
\text { az osztályközösségben. }\end{array}$ & 2,72 & 2,61 & $-0,11$ \\
\hline 18. & Jó a tanár-diák kapcsolat. & 2,64 & 2,61 & $-0,03$ \\
\hline 19. & $\begin{array}{l}\text { A pedagógusok partnerként } \\
\text { kezelik a szülőket. }\end{array}$ & 2,56 & 2,58 & $+\mathbf{0 , 0 2}$ \\
\hline 20 & Kicsi a lemorzsolódás. & 2,46 & 2,45 & $-0,01$ \\
\hline 21. & Elismerten jó iskola. & 2,83 & 2,53 & $-0,30$ \\
\hline
\end{tabular}

7.9. táblázat: A középiskolák és a gyakorlóiskola megítélésének átlagai és azok különbségei a nyolcadik osztályosok szüleinek értékelése alapján $(\mathrm{N}=293)$

A huszonegy itemnél a gyakorlóiskola esetében hatszor találtunk a középiskolák átlagától való pozitív irányú eltérést. A legnagyobb különbség a „Színvonalas a művészeti képzés” item esetében tapasztalható $(+0,49)$. A többi pozitív irányú eltérésnél az értékek jóval alacsonyabbak (+0,02 és +0,08 között). A középiskolák átlagától való negatív irányú eltérést tizenöt esetben találtunk. A legnagyobb negatív irányú különbséget az „Elismerten jó iskola” itemnél tapasztaltuk (-0,30). A második legnagyobb negatív irányú különbség „Az iskolából sok gyerek tanul tovább jó egyetemeken, föiskolákon” itemnél tapasztalható $(-0,23)$. A harmadik helyen a „Színvonalas az idegen nyelvek oktatása” item áll $(-0,21)$.

Ki kell emelnünk, hogy a szülők ismerik és elismerik a gyakorlóiskola fö profiljába tartozó művészeti képzést. A pozitív, illetve a negatív irányú átlagtól való eltérések a többi itemnél jelemzően nem túl nagyok. Ez arra utal, hogy a gyakorlóiskola a többi gimnáziumhoz hasonló megítélésben részesül. Elgondolkodtató azonban az iskola gimnáziumi tagozatának elismertségével kapcsolatos negatív irányú különbség. Különösen azért érdemes figyelni erre az értékre, mert a gyakorlóiskola általános iskolai tagozata átlagon felüli eredményt ért el ezen a területen. Természetesen itt is szem előtt kell tartani, hogy a szülők által legjobbnak tartott iskolákkal történt az összevetés.

A nyílt végü kérdésre nagyon kevés, mindössze öt válasz érkezett, a válaszok alátámasztják a zárt végű kérdésekre adott válaszokat: a szülők nem ismerik egyformán jól az iskolákat. A következő területeken tűnik jelentősebbnek a szülők tájékozatlansága: nem ismerik a tanárok tanítási elveit, nem tudják megítélni a gyakorlóiskolát és azt, hogy a pedagógusok szeretik-e a munkájukat és a gyerekeket. A második kérdéshez tíz szülő füzött megjegyzést. Hat válaszadó említette, hogy nem ismeri az iskolát, nincs információja róla. Egy szülő az iskolák bemutatkozását várja. Két szülő nyilatkozott úgy, hogy nem gimnáziumot 
választ a gyerekének, ezért nem tudja megítélni az iskolákat. Egy fó nem tudta értelmezni a kérdést. A 8. osztályos tanulók szülei hasonló problémákat jeleztek, mint az óvodások szülei. Kevés információval rendelkeznek az iskolákról. Mindenképpen érdemes ezt szem előtt tartani és nagyobb hangsúlyt fektetni a szülők és a leendők diákok tájékoztatására.

A 10. táblázatban összehasonlítottuk az itemek szülők által meghatározott fontossági sorrendjét a gyakorlóiskola tekintetében kialakult rangsorral. A táblázat harmadik és negyedik oszlopában kiemeltük az itemek rangsorát. Ezzel a kérdőívvel a gyakorlóiskola gimnáziumi tagozatának megítélése és a szülői elvárások közötti egyezéseket kívántuk feltárni. Ebben az esetben is feltételeztük, hogy az iskola profilja illeszkedik a szülői elvárásokhoz.

Kérjük, értékelje, hogy mennyire tartja fontosnak az alábbi állításokat az iskolaválasztás szempontjából! Válaszát soronként az alábbi számok bekarikázásával jelölheti:

$1=$ nem fontos

2 = közepesen fontos

3 = nagyon fontos

\begin{tabular}{|l|l|c|c|c|c|}
\hline itemek & $\begin{array}{c}\text { fontosság } \\
\text { átlaga }\end{array}$ & $\begin{array}{c}\text { gyakorló- } \\
\text { iskola } \\
\text { átlaga }\end{array}$ & $\begin{array}{c}\text { fontosság } \\
\text { rangsora }\end{array}$ & $\begin{array}{c}\text { gyakorló- } \\
\text { iskola } \\
\text { rangsora }\end{array}$ \\
\hline 1. & $\begin{array}{l}\text { A pedagógusok igazságo- } \\
\text { san értékelnek. }\end{array}$ & 2,94 & 2,58 & $\mathbf{1 .}$ & $\mathbf{1 2 .}$ \\
\hline 2. & $\begin{array}{l}\text { A gyerekek jól } \\
\text { érzik magukat } \\
\text { az osztályközösségben. }\end{array}$ & 2,93 & 2,61 & $\mathbf{2 .}$ & $\mathbf{6 , 5 .}$ \\
\hline 3. & Jó a tanár-diák kapcsolat. & 2,91 & 2,61 & $\mathbf{3 .}$ & $\mathbf{6 , 5 .}$ \\
\hline 4. & $\begin{array}{l}\text { A pedagógusok nyitottak, } \\
\text { rugalmasak, megértőek. }\end{array}$ & 2,9 & 2,63 & $\mathbf{4 .}$ & $\mathbf{5 .}$ \\
\hline 5. & $\begin{array}{l}\text { A pedagógusok szaktár- } \\
\text { gyi tudása kiemelkedően } \\
\text { jó. }\end{array}$ & 2,87 & 2,74 & $\mathbf{5 , 5 .}$ & $\mathbf{2 .}$ \\
\hline 6. & $\begin{array}{l}\text { A pedagógusok kiváló } \\
\text { nevelők. }\end{array}$ & 2,87 & 2,54 & $\mathbf{5 , 5 .}$ & $\mathbf{1 4 , 5 .}$ \\
\hline 7. & $\begin{array}{l}\text { Színvonalas az idegen } \\
\text { nyelvek oktatása. }\end{array}$ & 2,82 & 2,59 & $\mathbf{7 , 5 .}$ & $\mathbf{9 , 5 .}$ \\
\hline 8. & $\begin{array}{l}\text { A pedagógusok partner- } \\
\text { ként kezelik a szülőket. }\end{array}$ & 2,82 & 2,58 & $\mathbf{7 , 5 .}$ & $\mathbf{1 2 .}$ \\
\hline
\end{tabular}




\begin{tabular}{|c|c|c|c|c|c|}
\hline 9. & $\begin{array}{l}\text { A pedagógusok töreked- } \\
\text { nek a tanulásban lemara- } \\
\text { dók felzárkóztatására. }\end{array}$ & 2,75 & 2,66 & 9. & 3. \\
\hline 10. & $\begin{array}{l}\text { Az iskolából sok gyerek } \\
\text { tanul tovább jó egyeteme- } \\
\text { ken, fóiskolákon. }\end{array}$ & 2,53 & 2,59 & 10. & 9,5 . \\
\hline 11. & Elismerten jó iskola. & 2,49 & 2,53 & 11. & 16,5 . \\
\hline 12. & $\begin{array}{l}\text { Színvonalas az informati- } \\
\text { kai képzés. }\end{array}$ & 2,45 & 2,53 & 12,5 . & 16,5 . \\
\hline 13. & $\begin{array}{l}\text { Van lehetőség bontott } \\
\text { (kis létszámú) csoportok- } \\
\text { ban történő tanulásra. }\end{array}$ & 2,45 & 2,46 & 12,5 . & 19. \\
\hline 14. & Kicsi a lemorzsolódás. & 2,37 & 2,45 & 14. & 20. \\
\hline 15. & $\begin{array}{l}\text { Van lehetőség versenye- } \\
\text { ken való részvételre. }\end{array}$ & 2,27 & 2,75 & 15. & 1. \\
\hline 16. & $\begin{array}{l}\text { Sok szakkör, sportkör } \\
\text { indul a tanulói igények- } \\
\text { nek megfelelően. }\end{array}$ & 2,25 & 2,51 & 16. & 18. \\
\hline 17. & $\begin{array}{l}\text { Az iskola könnyen } \\
\text { megközelíthető. }\end{array}$ & 2,23 & 2,65 & 17. & 4. \\
\hline 18. & Nagyon színes a diákélet. & 2,04 & 2,6 & 18. & 8. \\
\hline 19. & $\begin{array}{l}\text { Van lehetőség külföldi } \\
\text { cserediákprogramban } \\
\text { való részvételre. }\end{array}$ & 1,94 & 2,37 & 19. & 21. \\
\hline 20. & $\begin{array}{l}\text { Megoldott } \\
\text { az akadálymentesítés. }\end{array}$ & 1,84 & 2,58 & 20. & 12. \\
\hline 21. & $\begin{array}{l}\text { Színvonalas a művészeti } \\
\text { képzés. }\end{array}$ & 1,82 & 2,54 & 21. & 14,5 . \\
\hline
\end{tabular}

7.10. táblázat: Az egyes szempontok fontosságának megítéléséből és a gyakorlóiskola ugyanezen szempontok szerinti értékeléséből származó átlagok és rangsorhelyek összehasonlítása a nyolcadik osztályosok szüleinek értékelése alapján $(\mathrm{N}=293)$ 
A táblázat harmadik és negyedik oszlopában kiemeltük az itemek rangsorát. Általában igen nagy eltéréseket találtunk a szülők által felállított fontossági sorrend és a gyakorlóiskola értékelésével kialakult rangsor között. Négy esetben találtunk megközelítően azonos rangsorbeli elhelyezkedést:

- „A pedagógusok nyitottak, rugalmasak, megértőek.” (4./5. hely)

- „Az iskolából sok gyerek tanul tovább jó egyetemeken, föiskolákon.” (10./9,5. hely)

- „Sok szakkör, sportkör indul a tanulói igényeknek megfelelően.” (16./18. hely)

- „Van lehetőség külföldi cserediákprogramban való részvételre.” (19./21. hely)

A legnagyobb eltéréseket a rangsorok között a következő esetekben tapasztaltuk:

- „A pedagógusok igazságosan értékelnek.” (1./12. hely)

- „Van lehetőség versenyeken való részvételre.” (15./1. hely)

• „Az iskola könnyen megközelíthető.” (17./4. hely)

Ebben az esetben is azt tapasztaljuk, hogy a fontosság átlagai és a gyakorlóiskola átlaga között nincs jelentős eltérés. A rangsorok esetében azonban az általános iskola megítéléséhez hasonló eredményeket kaptunk. Figyelemreméltó, hogy a 8. osztályosok szülei az óvodások szüleihez hasonlóan szintén a gyermekközpontú pedagógia és a jól működő közösség meglétét hangsúlyozzák. A szaktárgyi ismeretek megszerzésére, az iskolán kívüli tevékenységekre a gimnáziumi tagozaton is nagy hangsúlyt fektet a gyakorlóiskola. A szülők elismerik ezeket az értékeket, azonban fontosabbnak tartják, hogy a gyermekük jó kapcsolatot tartson fenn tanáraival és diáktársaival. Ez a szülői elvárás érthető, hiszen a gyermek közérzete befolyásolja iskolai teljesítményét.

\subsection{Az óvodások és a nyolcadik osztályosok szüleinek elvárásai}

A 11. táblázatban összehasonlítottuk az óvodások, illetve a nyolcadik osztályosok szüleinek véleményét az iskolaválasztásban szerepet játszó tényezők fontosságáról. Tizenöt azonos tartalmú itemet találtunk a két kérdőívben, az összehasonlítás ezekre az itemekre vonatkozik. A táblázat második és harmadik oszlopában a fontosságra vonatkozó átlagokat, a harmadik és a negyedik oszlopban a fontosság rangsorait tüntettük fel. 


\begin{tabular}{|c|c|c|c|c|c|}
\hline & itemek & $\begin{array}{l}\text { fontosság } \\
\text { átlaga } \\
\text { (óvodások } \\
\text { szülei) }\end{array}$ & $\begin{array}{l}\text { fontosság } \\
\text { átlaga } \\
\text { (általános } \\
\text { iskolások } \\
\text { szülei) }\end{array}$ & $\begin{array}{c}\text { fontosság } \\
\text { rangsora } \\
\text { (óvodások } \\
\text { szülei) }\end{array}$ & $\begin{array}{c}\text { fontosság } \\
\text { rangsora } \\
\text { (általános } \\
\text { iskolások } \\
\text { szülei) }\end{array}$ \\
\hline 1. & $\begin{array}{l}\text { A pedagógusok nyitottak, } \\
\text { rugalmasak, megértőek. }\end{array}$ & 2,99 & 2,90 & 1. & 4. \\
\hline 2. & $\begin{array}{l}\text { A gyerekek jól } \\
\text { érzik magukat } \\
\text { az osztályközösségben. }\end{array}$ & 2,95 & 2,93 & 4. & 2. \\
\hline 3. & $\begin{array}{l}\text { A pedagógusok igazságo- } \\
\text { san értékelnek. }\end{array}$ & 2,94 & 2,94 & 5. & 1. \\
\hline 4. & $\begin{array}{l}\text { A pedagógusok partner- } \\
\text { ként kezelik a szülőket. }\end{array}$ & 2,92 & 2,82 & 6. & 7,5 \\
\hline 5. & $\begin{array}{l}\text { A pedagógusok kiváló } \\
\text { nevelők. }\end{array}$ & 2,88 & 2,87 & 7. & 5,5 \\
\hline 6. & $\begin{array}{l}\text { A pedagógusok töreked- } \\
\text { nek a tanulásban lemara- } \\
\text { dók felzárkóztatására. }\end{array}$ & 2,69 & 2,75 & 9. & 9. \\
\hline 7. & $\begin{array}{l}\text { Színvonalas az idegen } \\
\text { nyelvek oktatása. }\end{array}$ & 2,62 & 2,82 & 10. & 7,5 \\
\hline 8. & $\begin{array}{l}\text { Az iskola könnyen } \\
\text { megközelíthető. }\end{array}$ & 2,51 & 2,23 & 11. & 17. \\
\hline 9. & $\begin{array}{l}\text { Van lehetőség bontott (kis } \\
\text { létszámú) csoportokban } \\
\text { történő tanulásra. }\end{array}$ & 2,46 & 2,45 & 12. & 12,5 \\
\hline 10. & Elismerten jó iskola. & 2,35 & 2,49 & 13. & 11. \\
\hline 11. & $\begin{array}{l}\text { Sok szakkör, sportkör } \\
\text { indul a tanulói igényeknek } \\
\text { megfelelően. }\end{array}$ & 2,34 & 2,25 & 14. & 16. \\
\hline 12. & $\begin{array}{l}\text { Van lehetőség versenyeken } \\
\text { való részvételre. }\end{array}$ & 2,24 & 2,27 & 15. & 15. \\
\hline 13. & Kicsi a lemorzsolódás. & 2,18 & 2,37 & 17. & 14. \\
\hline 14. & $\begin{array}{l}\text { Színvonalas a művészeti } \\
\text { képzés. }\end{array}$ & 2,09 & 1,82 & 18. & 21. \\
\hline 15. & $\begin{array}{l}\text { Megoldott } \\
\text { az akadálymentesítés. }\end{array}$ & 1,72 & 1,84 & 20. & 20. \\
\hline
\end{tabular}

7.11. táblázat: A fontosság átlaga és rangsora az óvodások és nyolcadik osztályosok szüleinek értékelése alapján $(\mathrm{N}=395)$ 
Mind az óvodások, mind a nyolcadik osztályosok szülei azonos helyre rangsorolták a következő tényezőket:

- „A pedagógusok törekednek a tanulásban lemaradók felzárkóztatására.” (9. hely)

- „Van lehetőség bontott (kis létszámú) csoportokban történő tanulásra.” (12. hely)

- „Van lehetőség versenyeken való részvételre.” (15. hely)

- „Megoldott az akadálymentesítés.” (20. hely)

Az óvodások szülei az alábbi állításokat tartják fontosabbnak

- „A pedagógusok nyitottak, rugalmasak, megértőek.” (1. kérdés)

- „A pedagógusok partnerként kezelik a szülőket.” (4. kérdés)

- „A az iskola könnyen megközelíthető.” (8. kérdés)

- „Sok szakkör, sportkör indul a tanulói igényeknek megfelelően.” (11. kérdés)

- „Színvonalas a müvészeti képzés.” (20. kérdés)

A következő állításokat az általános iskolások szülei fontosabbnak gondolják:

- „A gyerekek jól érzik magukat az osztályközösségben.” (2. kérdés)

- „A pedagógusok igazságosan értékelnek.” (3. kérdés)

- „A pedagógusok kiváló nevelők.” (5. kérdés)

- „Színvonalas az idegen nyelvek oktatása.” (7. kérdés)

- „Elismerten jó iskola.” (10. kérdés)

- „Kicsi a lemorzsolódás.” (13. kérdés)

A szakirodalom szerint a szülők az iskolákkal és a pedagógusokkal kapcsolatban konkrét elvárásokat fogalmaznak meg. A szülők az iskolának az oktatás (például az anyanyelvi nevelés, gondolkodásfejlesztés) mellett nagyobb szerepet szánnak a gyermek személyiségének formálásában (például a szocializációban, a tisztességes viselkedésre nevelésben) (Vizin, 2009, Mrázik, 2013) A pedagógusok a szülőkhöz hasonlóan fontos feladatuknak tartják az etikus magatartás formálását, a felnőtt viselkedési normák átadását. Felismerik a személyiségükben rejlő fejlesztő hatást (Lénárd, 2003). A kutatási eredmények alapján is megállapítható, hogy mind az óvodások, mind az általános iskolások szüleinél a legfontosabb tényezök a pedagógusok személyisége, attitüdjei. Nagyon fontos továbbá mindkét csoport számára, hogy a gyermekük jól érezze magát az osztályközösségben. A jó tanár-diák kapcsolat szintén igen hangsúlyos a szülők elvárásainál, bár a szakirodalomban a pedagógusok ritkábban említik (Lénárd, 2003). A pedagógusok nevelő munkája szinte azonos átlagot ér el mindkét részmintánál, de az általános iskolások szüleinél a pedagógusok nevelő szerepe hangsúlyosabbnak tűnik, ezt rangsorbeli elhelyezkedése is mutatja. A pedagógusok és a szülők partneri viszonya az óvodások szüleinek megítélése szerint fontosabb, mint az általános iskolások szüleinek 
véleménye szerint. Bár ez a tényező magas átlagot ért el mindkét vizsgált csoportnál, de az óvodások szüleinek rangsorában előrébb szerepel. A pedagógusok oktatómunkájával kapcsolatos elvárások között az adatok alapján igen fontos szerephez jut az idegen nyelvek oktatása, főképpen az általános iskolások szüleinél találtunk magas átlagot, és az óvodások szüleihez képest ők fontosabbnak tartják ez az állítást. Az iskola elismertsége is fontosabb az általános iskolások szülei számára, bár a rangsorban ez a tényező mindkét részminta esetén csak a középmezőnyben helyezkedik el.

A szülői elvárások és az iskola által fontosnak tartott oktatási-nevelési lehetőségek gyakran nincsenek összhangban egymással (Mrázik, 2013). Az átlagok és a rangsorok alapján is úgy tủnik, hogy a csoportbontás, a szakkörök, sportkörök, a versenyeken való részvétel mindkét részminta számára csupán közepesen jelentös tényezö. A müvészeti képzés igen alacsony átlagokkal szerepel mindkét szülői csoportnál, sőt az általános iskolások szüleinek megítélése szerint a színvonalas művészeti képzés csupán az utolsó helyen szerepel a fontossági rangsorban.

Az iskola elhelyezkedése és infrastruktúrája szintén nem tartozik a legfontosabb jellemzők közé. Az akadálymentesítés mindkét részmintánál az utolsó előtti helyen szerepel a rangsorban, az iskola könnyű megközelíthetősége az általános iskolások szülei szerint kevésbé fontos tényező, mint ahogyan azt az óvodások szülei megítélik.

A huszonkettedik itemnél a nyílt végủ kérdésre tizenegy válasz érkezett. Hét szülő a pedagógusokkal kapcsolatban írt megjegyzéseket, amelyek a pedagógusok attitűdjeire, módszertani kultúrájára, az iskola légkörére vonatkoztak. Két válaszadó a tanuló érdeklődését, képességeit jelölte meg az iskolaválasztás szempontjai között, két fö külső tényezők hatását emelte ki (iskola felszereltsége, hitélet biztosítása). A nyílt végủ kérdések összhangban vannak a kérdőív kérdéseivel - a pedagógus személyisége, az iskola légköre a legfontosabb tényező az iskolaválasztásnál a szülők számára.

\subsection{Az iskolaválasztást befolyásoló tényezők az óvodások és a nyolcadik osztá- lyosok szüleinek értékelése alapján}

A 12. táblázatban összehasonlítottuk az óvodások, illetve a nyolcadik osztályosok szüleinek véleményét az iskolaválasztást befolyásoló tényezőkről. Mindkét szülőcsoport azonos tartalmú itemek közül választhatott. A táblázat második és harmadik oszlopában az iskolaválasztást befolyásoló tényezőkre vonatkozó százalékos adatokat, a negyedik oszlopban a százalékok különbségeit, az ötödik és a hatodik oszlopban a két csoport válaszai alapján felállított rangsort mutatjuk be. 


\begin{tabular}{|c|c|c|c|c|c|c|}
\hline \multicolumn{7}{|c|}{$\begin{array}{l}\text { Mi befolyásolja leginkább az Ön döntését az iskolaválasztásban? Kérjük, karikázza be } \\
\text { az alábbi listában azt a legfeljebb három szempontot, amely befolyásolja a döntését! }\end{array}$} \\
\hline & $\begin{array}{l}\text { az iskolaválasztást } \\
\text { befolyásolja }\end{array}$ & 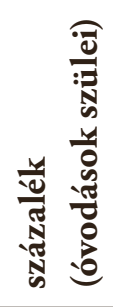 & 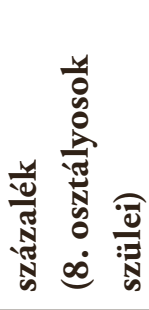 & 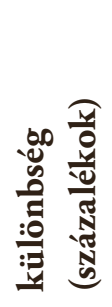 & 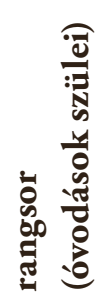 & 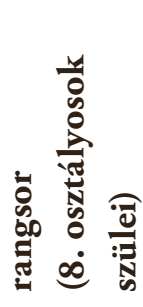 \\
\hline 1. & $\begin{array}{l}\text { az óvónő(k)/ } \\
\text { gyermekem általános } \\
\text { iskolai pedagógusai- } \\
\text { nak tanácsa, javaslatai }\end{array}$ & 49,0 & 52,3 & $+3,3$ & 2. & 2. \\
\hline 2. & $\begin{array}{l}\text { a gyermekem csoport- } \\
\text { jába/ osztályába járó } \\
\text { gyerekek szüleinek } \\
\text { döntése, véleménye }\end{array}$ & 10,4 & 7,1 & $-3,3$ & 6. & 7. \\
\hline 3. & $\begin{array}{l}\text { az iskolába/az adott } \\
\text { középiskolába járó } \\
\text { diákok szüleinek véle- } \\
\text { ménye, tapasztalatai }\end{array}$ & 55,2 & 57,9 & $+2,7$ & 1. & 1. \\
\hline 4. & $\begin{array}{l}\text { barátaim tanácsa, } \\
\text { javaslatai }\end{array}$ & 19,8 & 15,8 & -4 & 4. & 4. \\
\hline 5. & $\begin{array}{l}\text { gyermekem } \\
\text { (legjobb) barátjának } \\
\text { iskolaválasztása }\end{array}$ & 3,1 & 5,3 & $+2,2$ & 8. & 8. \\
\hline 6. & $\begin{array}{l}\text { családi hagyományok } \\
\text { az iskolaválasztásban }\end{array}$ & 15,6 & 12 & $-3,6$ & 5. & 5. \\
\hline 7. & $\begin{array}{l}\text { az iskola közelsége } \\
\text { lakóhelyünkhöz }\end{array}$ & 42,7 & 27,1 & $-15,6$ & 3. & 3. \\
\hline 8. & $\begin{array}{l}\text { Ezek közül egyik sem } \\
\text { befolyásol. }\end{array}$ & 4,2 & 8,6 & $+4,4$ & 7. & 6. \\
\hline
\end{tabular}

7.12. táblázat: Az iskolaválasztást befolyásoló tényezők kiválasztásának százalékos aránya és a válaszok alapján felállított rangsor az óvodások és nyolcadik osztályosok szüleinek értékelése alapján $(\mathrm{N}=395)$ 
Az iskolaválasztást befolyásoló nyolc tényező rangsora szinte teljesen azonos az óvodások, illetve a nyolcadik osztályosok szüleinél. Eltérést két esetben találtunk: „a gyermekem csoportjába/osztályába járó gyerekek szüleinek döntése, véleménye” az óvodások szüleinél hatodik helyen, a nyolcadik osztályosok szüleinél hetedik helyen szerepel, illetve az „ezek közül egyik sem befolyásol” válasz az óvodások szüleinél a hetedik helyen, míg a nyolcadik osztályosok szüleinél hatodik helyen jelenik meg. A százalékos arányok közötti eltérések a két részminta között elenyészőek, 2,2 és 4,4 százalék közöttiek, ami a két szülöcsoport vélekedéseinek hasonlóságát támasztja alá. Az iskolaválasztást leginkább befolyásoló tényező mindkét részminta esetén „az iskolába/az adott középiskolába járó diákok szüleinek véleménye, tapasztalatai”, de szintén nagy arányban választották a szülők mindkét csoportban „az óvónő(k)/gyermekem általános iskolai pedagógusainak tanácsa, javaslatai” állítást is: az óvodások szüleinél a válaszadók 49 százaléka, a nyolcadik osztályosok szüleinek 52,3 százaléka tartja fontosnak ezt a tényezőt az iskolaválasztásnál. A legkevésbé befolyásolja az iskolaválasztást mindkét részmintánál „a gyermek (legjobb) barátjának iskolaválasztása” (az óvodások szüleinél 3,1\%, a nyolcadik osztályosok szüleinél, 5,3\%). Feltűnően nagy a különbség a két részminta válaszai között annál az itemnél, amely az iskola lakóhelyhez való közelségére vonatkozik („az iskola közelsége lakóhelyünkhöz”): az óvodások szüleinek 42,7 százaléka, míg a nyolcadik osztályosok szüleinek csupán 27,1 százaléka tartja fontosnak az iskolaválasztásnál ezt a szempontot. A különbség valószínűleg azzal magyarázható, hogy az alsó tagozatos diákokat még a szülők kísérik az iskolába, így számukra lényeges az iskola közelsége, a középiskolás diákok viszont már önállóan közlekednek, ezért esetükben már nem annyira lényeges a távolság. Az adatokból kitűnik, hogy a gyermek életkorától teljesen függetlenül mindkét részmintánál az adott iskolába járó diákok szüleinek véleménye, illetve a pedagógusok tanácsa a legfontosabb tényezö az iskolaválasztásnál.

A kilencedik, nyílt végü kérdésre az óvodások szülei esetében huszonkét válasz érkezett, hat szülő a pedagógusok személyiségét emeli ki. A nyílt napon szerzett tapasztalatok csupán a három szülőnél jelentenek fontos tényezőt, az iskolaválasztásnál az iskola hírneve, külsö adottságai, képzési kinálata a legkevésbé fontos szempontok a szülök számára, ezt egy szülő említette. Négy szülő szerint befolyásoló tényező még a nagyobb testvér iskolájának választása, három szülő az iskola légkörét, ketten a gyermek képességeinek fejlesztését, az oktatás minőségét emelték ki.

A kilencedik, nyílt végü kérdésre a nyolcadik osztályosok szülei esetében száznégy válasz érkezett. A válaszadók többsége (64\%) úgy gondolja, hogy az iskolaválasztást gyermekük döntése, tervei, érdeklődési köre, tudása és képességei befolyásolják, tehát nagy teret adnak a gyermek önálló választásának. A továbbtanulási szándék, a tanulmányi eredmény, az oktatás színvonala, az iskola presztízse csupán a válaszadók 5-6\%-a számára fontos. A válaszolók 1-2\%-a említ egyéb befolyásoló tényezőket is (idegennyelv-oktatás, az iskola képzési 
struktúrája, az iskola belső megítélése, a testvér is oda járt, SNI-s gyermeknek megfelelő iskola, nyílt napok, iskolai légkör, motiváló, képességfejlesztő iskola, gyermekkel való közös döntés, a pályaválasztási tanácsadó véleménye, kis tanulói létszám). Megjegyezzük, hogy a nyílt napokat csupán két válaszadó említi befolyásoló tényezőként, miközben a második kérdésnél több megjegyzés is érkezett arra vonatkozóan, hogy az iskolákat a szülők csak a nyílt napok után tudnák jellemezni.

\section{Az eredmények értékelése}

Az első hipotézisünkben azt feltételeztük, hogy a gyakorlóiskola a város elismert oktatási intézményei közé tartozik. Ez a hipotézisünk az óvodások szüleinek véleménye alapján beigazolódott. A gyakorlóiskola általános iskolai tagozata átlagon felül teljesít a szülők megítélése szerint. Kissé eltér ettől a 8. osztályosok szüleinek véleménye. A gyakorlóiskola gimnáziumi tagozatának eredményei ugyan elmaradnak a másik két választott iskola átlagától, de a különbség nem jelentős. A gimnáziumi tagozat megítélése tehát a megkérdezett szülők szerint jó, bár nem kiemelkedő. Figyelemreméltó, hogy a két tagozat megítélése között jelentős különbség tapasztalható.

A második hipotézisünkben a gyakorlóiskola képzési profilja és a szülők elvárásai közötti összhangról írtunk. Úgy ítéljük meg, hogy a feltételezésünk nem igazolódott. Mindkét részminta esetén azt tapasztaltuk, hogy bár a szülők nagyra értékelik a gyakorlóiskola teljesítményét, de mégsem feltétlenül a megítélésük szerint első helyen szereplő értékeket tartják a legfontosabbaknak. A szaktárgyi ismeretek átadása, a versenyeredmények rendkívül hangsúlyosak egy iskola megítélésében, de a megkérdezett szülők számára sokkal fontosabb az, hogy a gyermekük elfogadó, gyermekközpontú légkörben tanulhasson.

Harmadik hipotézisünk az iskolaválasztásra befolyást gyakorló tényezőkre vonatkozott. Feltételeztük, hogy a szakirodalmi adatokkal összhangban a mintánkban szereplő szülőket is a családtagok, ismerősök véleménye befolyásolja leginkább az iskolaválasztásban. Az eredmények igazolták hipotézisünket azzal a kiegészítéssel, hogy a megkérdezett szülők szerint az iskolaválasztás szempontjából a leghangsúlyosabb azoknak az ismerősöknek a véleménye, akiknek gyermekei a gyakorlóiskolába járnak. Az iskola belső megítélése tehát rendkívül nagy hatást gyakorol az iskolaválasztásra. Nagyon fontos, hogy az iskola belső megítélésével összhangban legyenek a szülők elvárásai. A második legfontosabb tényező az óvónők, illetve a gyermek általános iskolai tanárainak tanácsa, javaslatai. A nyílt végü kérdésekre adott válaszok a 8. osztályosok szüleinél nagyon gyakran a gyermek saját döntését emelik ki. 
Negyedik hipotézisünkben a gyermeket oktató-nevelő szakemberek véleményének fontosságát fogalmaztuk meg az iskolaválasztás szempontjából. Hipotézisünk beigazolódott. Az óvónők és az általános iskolai tanárok véleménye a második legfontosabb befolyásoló tényező a megkérdezett szülők körében. Nagyon fontosnak tartjuk, hogy az iskola pozitív külső megítélésének alakításában a gyakorlóiskola minél inkább szem előtt tartsa az óvodák, általános iskolák véleményét. Intenzív kapcsolatot kell ápolni ezekkel az intézményekkel, minden lehetséges fórumon meg kell ismertetni velük az iskola elfogadó, gyermekközpontú értékrendjét.

\section{5. Összegzés}

A szülők iskolaválasztással kapcsolatos elvárásai és a gyakorlóiskoláról kialakult kép jelentősen eltér egymástól. Mindkét részminta esetén a pedagógus személyisége és az iskola légköre a legfontosabb tényező az iskolaválasztásnál, és a szülők nem az iskola profiljából adódó lehetőségekre helyezik a hangsúlyt (például csoportbontás, versenyek, szakkörök).

Mindkét részminta esetében a válaszadók legkevésbé a gyakorlóiskolát tudták értékelni, a szülők több mint kétharmada nem adott érdemi választ a gyakorlóiskolával kapcsolatban.

A gyakorlóiskolát a nyolcadik osztályosok szülei alacsonyabb pontszámokkal értékelték, mint az óvodások szülei. Mind az iskola elismertségét, mind az idegen nyelvek oktatásának színvonalát gyengébbre minősítették a nyolcadik osztályosok szülei. Míg az óvodások szüleinél az idegen nyelv oktatásának színvonala pozitív értékelést kapott, addig ez a tényező a nyolcadik osztályosok szüleinek esetében már negatív előjellel szerepelt.

A színvonalas művészeti képzést a gyakorlóiskolában ugyan mindkét részminta magas pontszámmal értékelte, de az iskolaválasztásnál ez a terület mindkét részminta esetében kevésbé fontos tényező.

\section{Javaslatok}

A gyakorlóiskola profiljában a mủvészeti képzés az egyik leghangsúlyosabb elem. Hasznos lehet a képzés megismertetésének erősitése, újragondolása. Az iskolaválasztást befolyásoló tényezők közül mindkét részminta esetén a legfontosabb az adott iskolába járó diákok szüleinek véleménye, tapasztalatai, valamint az óvónők, általános iskolai tanárok tanácsa, javaslatai. Célszerủ lehet a gyakorlóiskola kommunikációs stratégiájának, marketingtevékenységének újragondolása. 
A nyílt végü kérdésekre adott válaszok alapján az óvodások szüleit az iskolaválasztásnál leginkább a tanítónők személyisége befolyásolja. A nyolcadik osztályosok szülei azonban kiemelkedően nagy arányban a gyermek döntésére hagyatkoznak az iskolaválasztásnál. Ez alapján úgy tűnik, hogy az iskolaválasztás előtt álló nyolcadik osztályos gyerekeket kell leginkább megszólítani, számukra kell vonzóvá tenni a gyakorlóiskolát. Megjegyezzük, hogy a nyílt napok kevésbé fontosak a szülők számára, mint ahogyan azt feltételeztük. A nyílt nap leginkább csak megerősíti a gyermeket a választásában.

Hangsúlyozzuk, hogy a kitöltésnél viszonylag sok volt a bizonytalan, az iskolákkal kapcsolatban tájékozatlan szülő. A szülői vélemények sok esetben nem a tényleges színvonalat, hanem az arról elterjedt képet tükrözik. Az összehasonlítás azokkal az iskolákkal történt, amelyeket a szülők gyermekük számára jónak ítéltek, tehát a feltételesen választott iskolákhoz viszonyítva kell értékelni a gyakorlóiskola értékelésben elfoglalt helyét.

A gyakorlóiskolának azt is érdemes lenne elemezni, hogy miért éppen a szülők által fontosnak tartott tényezőkben ér el a gyakorlóiskola viszonylag alacsony értékeket (például elfogadó, gyermekközpontú légkör). Egyrészt meg kellene mindent tenni annak érdekében, hogy ezekben kérdésekben jobbak legyenek a valóságos mutatók, illetve ott, ahol jók (például a pedagógusok kiemelkedő szaktárgyi tudása, versenyeken való részvétel), erről folyamatosan tájékoztatni kellene a szülőket. Továbbá meg kell határozni, hogy mely tényezők vonatkoznak az iskoláról kialakult képre, és melyek az iskola tényleges tevékenységére. Ezt csak a nevelőtestület döntheti el a rendelkezésére álló egyéb adatok alapján.

Bízunk benne, hogy a kutatásunk eredményei segíthetik a gyakorlóiskolát annak meghatározásában, hogy miben kell változtatni az iskola tevékenységén, és melyek azok a jellemzők, amelyekkel kapcsolatosan a tájékoztatást differenciáltabbá, hatékonyabbá kell tenni.

\section{Felhasznált irodalom:}

Berényi Eszter, Berkovits Balázs és Erőss Gábor (2005): Iskolaválasztás az óvodában: A korai szelekció gyakorlata. Educatio, 4. 805-824.

http://polc.ttk.pte.hu/tamop-4.1.2.b.2-13/1-2013-0014/24/index.html (Utolsó letöltés: 2018. 01. 19.)

Lénárt Sándor (2003): Naiv nevelési nézetek. Iskolakultúra. 5. 76-82.

Mrázik Julianna (2015): Neveléselmélet: digitális jegyzet az osztatlan tanárképzésben és a tanártovábbképzésben résztvevők számára. Pécs, Pécsi Tudományegyetem Bölcsészettudományi Kar Neveléstudományi Intézet. http://nbn.urn.hu/N2L?urn:nbn:hu-135 601, (Utolsó letöltés: 2018. 01. 10.) 
Pusztai Gabriella (2009): A társadalmi tőke és az iskolai pályafutás. Budapest, Új Mandátum Kiadó.

Sántha Kálmán (2015): Trianguláció a pedagógiai kutatásban. Budapest, Eötvös József Könyvkiadó.

Solymosi Katalin (2013): Iskolaválasztás: a háttérben húzódó motivációk és nézetek. In: Karlovitz J. T., Torgyik J. (szerk.): Vzdelávanie, výskum a metodológia = Oktatás, kutatás és módszertan: Neveléstudományi és Szakmódszertani Konferencia. 771. Konferencia helye, ideje: Komárno, Szlovákia.

Tóth Edit (2015): Az országos kompetenciamérés hatása a tanítási munkára pedagógusinterjúk alapján. Magyar Pedagógia. 2. 115-138.

https://doi.org/10.17670/MPed.2015.2.115

Vizin Gabriella (2009): Miért nem működik még mindig? ...avagy érvek az iskolapszichológusi hálózat kiépítése mellett. Iskolakultúra. 7-8. 97-113. 